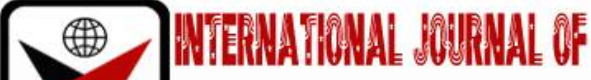

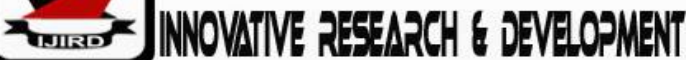

ISSN 2278-0211 (Online)

\section{Estimating the Willingness to Pay for Ecosystem Services in a Sustainable Rubber Agroforestry System within the Tropical Zones in Nigeria}

Chioma Okwu-Abolo
Research Officer, Department of Research Outreach
Rubber Research Institute of Nigeria (RRIN), Nigeria
Adekunle Micheal Femi
Professor, Department of Forestry and Wildlife,
Federal University of Agriculture, Abeokuta (FUNAAB), Nigeria
Okojie, Lukeman
Professor, Department of Agricultural Economics and Farm Management,
Federal University of Agriculture, Abeokuta (FUNAAB), Nigeria
Igberase Shulamite
Research Officer, Department of Research Outreach,
Rubber Research Institute of Nigeria (RRIN), Nigeria
Sunday Oghenetega
Research Officer, Department of Research Outreach,
Rubber Research Institute of Nigeria (RRIN), Nigeria

\begin{abstract}
:
Ecosystem services are services provided by the natural environment that provides benefit to people and more so improves their well-being. These services are mostly intangible benefits which generates low or no actual monetary value, this has resulted to these services being poorly reflected in national regulations and policies by the decision makers. Thus, this paper focused on estimating willingness to pay for ecosystem services in a Rubber Agroforestry System (RAS). Multi-stage sampling procedure involving purposive and random sampling were adopted using a structured questionnaire to select 240 respondents for the study.

Dichotomous choice-contingent valuation method of the Willingness-To-Pay (WTP) format and binary choice logit model was adopted to elicit the optimal bid amount for Ecosystem Services in RAS. Data obtained were analyzed using descriptive and inferential statistics. Result revealed that RAS contributed to the livelihoods of the people. Majority of the respondents in Edo (80\%) and Delta (79.2\%) States were willing to pay for the derived ecosystem services from RAS elicited through the optimal bids while $20 \%$ and $20.8 \%$ in Edo and Delta States respectively were not willing to pay for the ecosystem services in RAS. Total WTP per year were $\# 74,565,369.6$ and $\# 43,033,105.5$ while the respondent mean WTP per month for ecosystem services were $\$ 10.33$ and $\$ 10.50$ in Edo and Delta States respectively. Bid offered, income and education had a significant $(P<0.05)$ negative effect while years of experience and attitude of RAS farmers had a significant $(P<0.01)$ positive effect on the likelihood of bid acceptance of the WTP for the ecosystem services of $R A S$. These amounts represented the monthly monetary values of the ecosystem services derivable from RAS

This study concluded that respondents highly valued RAS and were willing to contribute a part of their income to ensure the continued existence of RAS, the study recommended that an ecosystem service payment policy should be formulated to sustain the multiple benefits derivable from Rubber based systems.
\end{abstract}

Keywords: Ecosystem services, rubber agro forestry system, contingent valuation, willingness-to-pay (WTP)

\section{Introduction}

In the last few decades, the economic valuation of natural or man-made forests around the world has included environmental, social and economic aspects of forest ecosystem. Forest ecosystem can be described as a valuable enterprise that provides a wide array of goods and services. Amongst the range of goods and services which are known to improve the well-being of the society as a whole includes the non-market as well as marketed good and services (Frank and Pieter, 1997). However, some of the forest goods have observable prices as they are sold in the market while some of them generates low or no actual monetary value, the reason being that the goods or services are non-marketed or that 
their market values are difficult to quantify. Thus, their neglection in development planning by the decision makers. One of such forest ecosystems is the Rubber Agroforestry systems (RAS).

Rubber Agroforestry system is an innovative approach to improve the lives of smallholders by the deliberate integration of high value trees, arable crops and animals into Rubber plantations. This system which provides a wide range of ecosystem services like increasing soil fertility, rehabilitation of degraded land, restoration of above and below-ground diversity, carbon sequestration, protection of soil and watersheds, enhance beauty of scenery especially when diverse tree species are dispersed within field has proven to be profitable and environmentally sustainable (Asaah et al., 2014; Esekhade et al., 2014). These ecosystem services have been grouped into four primary categories; provisioning, regulating, cultural and supporting services according to MEA, (2005) and Constanza et al., (1997), and has become an important model for linking the functioning of ecosystems to human welfare (MEA, 2005 and Sukhdev, 2010).

The loss of the forest ecosystem and by implication its services has been due to some drivers, such as climate change, pollution, overexploitation, land-use change and urbanization. According to MEA (2005), $60 \%$ of the ecosystem services assessed globally are either degraded or being used unsustainably (Okojie and Abiola, 2014). This situation can be attributed to lack of sufficient incentives for land owners to protect forest ecosystem and its services as they may receive little or no benefits from them.

Attaching a monetary value on a good or service can help to provide an incentive for people to produce and conserve the system. Various methods such as revealed and stated preference methods have been used to attach monetary values to non-market goods and services from the forests by economists (White and Lovett, 1999; Ajewole, 2001). The revealed preference methods are based on how individual actually behaved in a real market situation while the stated preference methods are based on how individuals say they will behave under hypothetical market situation. Prominent among the stated preference method is the contingent valuation method (CVM) which is a means of quantifying public preference and willingness-to-pay (WTP) for forest goods and services or willingness to accept compensation for losing access to the forest goods and services (Adekunle, 2005).

Thus, there is need for a comprehensive assessment of the goods and services provided by various forest ecosystems using economic valuation methods which may contribute to more informed decision making (Frank and Pieter, 1997). Although, Mather and Chapman (1995) argue that the object of valuation is not the environment itself, but rather the people's preferences for changes in the state of their environment. The authors opined that the importance is measured by preferences which in turn are measured by the summation of many individuals Willingness-To-Pay (WTP) for the environmental services of the system. Thus, in an economic context, the true value of a system must include both its productive value and the indirect use of the environmental service function and relevant existence value (Ajewole, 2000). Thus, it is the interest of this study to estimate the willingness to pay for ecosystem services provided in a Rubber agroforestry system (RAS).

\section{Methodology}

\subsection{Study Area}

The study areas are Edo and Delta States, Nigeria. Edo State lies between longitudes 050 04'E and 06 43'E and latitudes $05^{0} 44^{\prime} \mathrm{N}$ and $07^{\circ} 34^{\prime} \mathrm{N}$ and covers a land area of about 19,794 km while Delta State lies between longitudes $5^{\circ} 00^{\prime}$ and $6^{0} 45^{\prime} \mathrm{E}$ and latitudes $5^{0} 00^{\prime}$ and $6^{0} 30^{\prime} \mathrm{N}$ with a total land area of $17,011 \mathrm{~km}^{2}$. The climate of the States is characterized by two distinct seasons -the wet and dry seasons, with an average rainfall ranging from 1500 mm in the extreme north of the State to $2500 \mathrm{~mm}$ in the south. The temperature averages about $25^{\circ} \mathrm{C}$ in the rainy season and $28^{\circ} \mathrm{C}$ in the dry season. The climate is humid tropical in the south to sub-humid in the north with oil palm and Rubber growing reasonably well. Edo State is presently divided into 18 Local Government Areas (LGAs) with a population estimate of 7,218,332 while Delta State is presently divided into 25 Local Government Areas with a population estimate of 4,098,391 according to NPC (2006). 


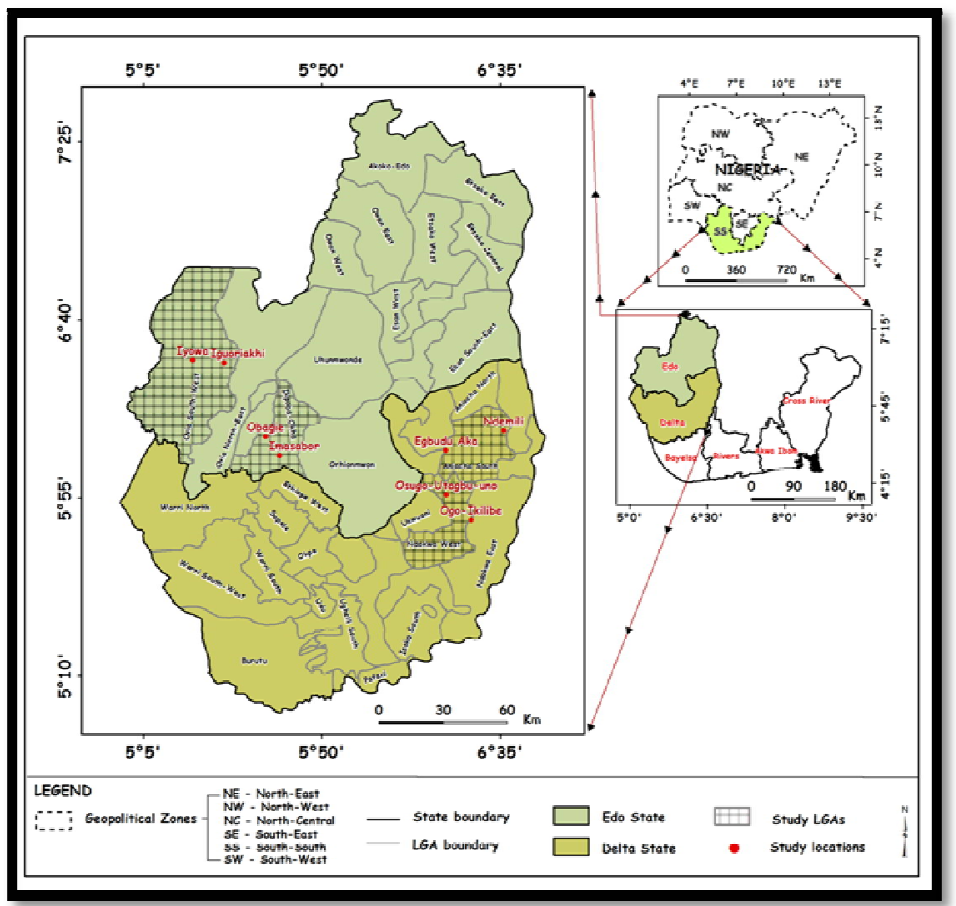

Figure 1: Map of the Study Area Showing the Study Zones Source: Produced Using Arcmap 10.1

\subsection{Data Collection}

To estimate respondent's willingness to pay (WTP) for the ecosystem services derived from the continuous existence of the Rubber Agroforestry system, a structured questionnaire was designed to elicit information from the respondents adopting the snowball non-probability sampling techniques (Adekunle, 1998). The monetary value elicitation survey procedure was based on open-ended and close-ended dichotomous-choice contingent valuation method (DC-CVM). A pre-test open-ended dichotomous-choice contingent valuation method (DC-CVM) survey was carried out, from which the unique bids and their optimal sample allocations were worked out. This was then used in the actual DC-CVM survey. WTP can be defined as the maximum amount a respondent is willing to pay for a given quantity of an item (Kalish and Nelson,1991; Varian,1992).

The concept of WTP for a service was first explained to the respondents. Thereafter, with an open format, the respondents were asked about the maximum price that they would pay for the ecosystem services derived from the RAS system, the values obtained were $\$ 50, \$ 100, \$ 200, \$ 500, \$ 1000$ and $\$ 5000$. In the second question, which formed the actual DC-CVM survey, ballot papers containing the above-mentioned amount after taking off outliers were placed in a bag and each respondent was invited to pick one and then asked: "Are you willing to pay the amount/value stated on the paper?".

Also, information on socio-characteristics, farm characteristics and respondent's perception of ecosystem services in RAS were also collected through a multiple item Likert scale that was developed by Del (2010). The questionnaire was administered to respondents in February, 2019.

\subsection{Sampling Technique}

Multi-stage sampling procedure involving purposive and simple random sampling was adopted in this study. The first stage involved the selection of the primary unit; Edo and Delta States. In the second stage, two (2) Local Government Areas (LGA) were purposively selected where Rubber Agroforestry System was practiced in each State (Figure 1). The third stage involved purposive selection of two (2) communities in each L.G.A while the fourth stage was the selection of thirty (30) respondents in each community adopting the snowball approach, which gave a total of two hundred and forty (240) respondents for the study area (Table 1). 


\begin{tabular}{|c|c|c|c|c|c|}
\hline State & LGA & Community & GPS coordinate & No. of respondent & Total \\
\hline \multirow[t]{4}{*}{ Edo } & \multirow[t]{2}{*}{$\begin{array}{l}\text { Ovia South } \\
\text { West }\end{array}$} & Iguoriakhi & $\begin{array}{l}\mathrm{N}^{0} 6^{\circ} 29.039^{\prime} \\
\mathrm{E}^{\circ} 05^{\circ} 25.307^{\prime}\end{array}$ & 30 & \multirow[b]{4}{*}{120} \\
\hline & & Iyowa & $\begin{array}{c}\text { N06 }^{\circ} 29.692^{\prime} \\
\text { E005 }^{\circ} 37.406^{\prime}\end{array}$ & 30 & \\
\hline & \multirow[t]{2}{*}{ Ikpoba Okha } & Imasabor & $\begin{array}{c}\text { N0605.638' }^{\prime} \\
\text { E00539.355' }\end{array}$ & 30 & \\
\hline & & Obagie Nevbosa & $\begin{array}{c}\text { N06¹0.394' }^{\prime} \\
\text { E00535.704' }\end{array}$ & 30 & \\
\hline \multirow[t]{4}{*}{ Delta } & \multirow[t]{2}{*}{ Ndokwa West } & $\begin{array}{c}\text { Osugo-utagbu } \\
\text { uno } \\
\end{array}$ & $\begin{array}{l}\mathrm{N}^{\circ} 42^{\prime} 23.7^{\prime} \\
\mathrm{E}^{\circ} 27^{\prime} 35.5^{\prime}\end{array}$ & 30 & \multirow{5}{*}{$\frac{120}{240}$} \\
\hline & & Ogo-Ikilibe & $\begin{array}{l}\text { N 05ㅇ⒌004' }^{\circ} \\
\text { E 06²0.095' }\end{array}$ & 30 & \\
\hline & \multirow[t]{2}{*}{ Aniocha South } & Egbudu Aka & $\begin{array}{c}\text { N06 }^{\circ} 07.115^{\prime} \\
\text { E006 }^{\circ} 22.171^{\prime}\end{array}$ & 30 & \\
\hline & & Ndemili & $\begin{array}{l}\mathrm{N}^{\circ} 54^{\prime} 90.8^{\prime} \\
\mathrm{E} 6{ }^{\circ} 19^{\prime} 77.6^{\prime \prime}\end{array}$ & 30 & \\
\hline Total & & & & & \\
\hline
\end{tabular}

Table 1: Sampling Plan for Socio-Economic Valuation

\subsection{Analytical Procedures}

A combination of analytical tools was employed during the study. These included descriptive statistics, dichotomous-choice contingent valuation (DC-CVM) method and binary choice logit regression model.

The descriptive analysis involved the use of tables, frequency, mean and percentages which was used to describe the socio-economic characteristics of the respondents. The DC-CVM and the logit model were used to assess the willingness to pay for ecosystem services derivable from the RAS. The maximum likelihood estimates of the logit regression model provided the coefficient necessary to compute the monetary value of the ecosystem services as expressed by the WTP. The logit regression model is based on Hanemann (1984). Approach as used by Cooper and Loomis (1992), Turcin and Giraud (2001) and Okojie and Abiola (2014) as follows: This assessment as conceptualized through the willingness to pay (WTP) from the respondent's perspective is as derived from the following models:

$$
\mathrm{P}_{\mathrm{i}}=-\frac{1}{\left(1+\exp \left(\alpha+\mathrm{B}_{\mathrm{i}} \mathrm{X}_{\mathrm{i}}\right)\right.}
$$

Where:

$P_{i}=$ Respondents acceptance probability to the bid offered.

$\mathrm{B}_{i}=$ Vector representing the coefficients of all covariates including that of the bid $\left(\mathrm{B}_{\mathrm{i}}\right)$

$\mathrm{X} i=$ Vector representing all covariates

The covariates are as follows;

$\mathrm{X}_{1}=$ bid offered, $\mathrm{X}_{2}=$ Income, $\mathrm{X}_{3}=$ Educational level, $\mathrm{X}_{4}=$ Household size, $\mathrm{X}_{5}=$ Gender, $\mathrm{X}_{6}=$ years of experience, $\mathrm{X}_{7}=$ Contact with extension agent and $X_{8}=$ RAS dummy

ii. The ecosystem services benefits were computed based on the restricted mean WTP following Cooper and Loomis (1992), and approach of Okojie and Abiola, (2014) was adopted. The procedure is as follows:

$\mathrm{P}^{-}=1 /|\beta|^{*} \ln \left(1+\exp ^{\mathrm{a}}\right)$.....

Where:

$\mathrm{P}^{-}=$restricted mean WTP

$\mathrm{a}=$ intercept

$\beta=$ coefficient of bid

The determinants of the WTP for ecosystem benefits derived from RAS were established from the logit regression from where relevant coefficients were estimated from the maximum likelihood procedure.

\section{Result and Discussion}

Socio-economic characteristics of respondents considered were gender, age, educational level, income and their WTP for the ecosystem services derived from RAS. The respondents were predominantly males (77.5 \%). The respondent's age ranged from 35 years to above 65 years. The proportion of the respondents within the age class of $46-$ 55 years with a pooled percentage distribution of $35.83 \%$ constituted the largest percentage. The respondents consisted of $13.75 \%$ that had no formal education, $15 \%$ that had primary education, $33.75 \%$ had secondary education and $37.5 \%$ had tertiary level (OND and HND) education. Majority (34.17\%) of the respondents earn a monthly income from their Rubber farms between $\$ 50,000$ - $\$ 100,000$ (Table 2). Furthermore, $79.58 \%$ of the respondents were willing to pay for the ecosystem services derived from the RAS elicited through the optimal bids, while $20.42 \%$ were not willing to pay. 


\begin{tabular}{|c|c|c|c|c|c|c|}
\hline Variables & Edo State & & Delta State & & pooled & \\
\hline & Feq. & \%tage & Feq. & \%tage & Feq. & \%tage \\
\hline \multicolumn{7}{|l|}{ Gender } \\
\hline Male & 109 & 90.83 & 77 & 64.17 & 186 & 77.5 \\
\hline Female & 11 & 9.167 & 43 & 35.83 & 54 & 22.5 \\
\hline Total & 120 & 100 & 120 & 100 & 240 & 100 \\
\hline \multicolumn{7}{|l|}{ Age } \\
\hline$<35$ & 18 & 15 & 7 & 5.83 & 25 & 10.42 \\
\hline $36-45$ & 23 & 19.17 & 29 & 24.17 & 52 & 21.67 \\
\hline $46-55$ & 43 & 35.83 & 43 & 35.83 & 86 & 35.83 \\
\hline $56-65$ & 32 & 26.67 & 37 & 30.83 & 69 & 28.75 \\
\hline Above 65 & 4 & 3.33 & 4 & 3.33 & 8 & 3.33 \\
\hline Total & 120 & 100 & 120 & 100 & 240 & 100 \\
\hline \multicolumn{7}{|l|}{$\begin{array}{c}\begin{array}{c}\text { Educational } \\
\text { level }\end{array} \\
\end{array}$} \\
\hline $\begin{array}{l}\text { No formal } \\
\text { education }\end{array}$ & 26 & 21.67 & 7 & 5.83 & 33 & 13.75 \\
\hline Primary & 18 & 15 & 18 & 15 & 36 & 15 \\
\hline Secondary & 41 & 34.17 & 40 & 33.33 & 81 & 33.75 \\
\hline Tertiary & 35 & 29.17 & 55 & 45.84 & 90 & 37.5 \\
\hline Total & 120 & 100 & 120 & 100 & 240 & 100 \\
\hline \multicolumn{7}{|l|}{ Income $(\mathrm{N})$} \\
\hline Below 50000 & 19 & 15.83 & 23 & 19.17 & 42 & 17.5 \\
\hline $\begin{array}{l}50001- \\
100000 \\
\end{array}$ & 39 & 32.5 & 43 & 35.83 & 82 & 34.17 \\
\hline $\begin{array}{c}100001- \\
150000\end{array}$ & 19 & 15.83 & 14 & 11.67 & 33 & 13.75 \\
\hline $\begin{array}{l}150001- \\
200000\end{array}$ & 17 & 14.17 & 12 & 10 & 29 & 12.08 \\
\hline $\begin{array}{c}200001- \\
250000\end{array}$ & 6 & 5 & 6 & 5 & 12 & 5 \\
\hline Above 250001 & 20 & 16.67 & 22 & 18.33 & 42 & 17.5 \\
\hline Total & 120 & 100 & 120 & 100 & 240 & 100 \\
\hline
\end{tabular}

Table 2: Socio-Economic Characteristics of Respondents

Source: Field Survey (2019)

$(\# 362=1$ USD)

The DC-CVM analytical tool was used to derive the value of the ecosystem services in a Rubber Agroforestry system. From the study, ecosystem services valued within the Rubber agro forestry system were clean water provisioning, clean air, nutrient cycling and biodiversity. The actual Dichotomous-Choice Contingent Valuation Method (DC - CVM) and the logit regression were used to assess the ecosystem services derived from the RAS in the study areas. The result showed that the maximum likelihood estimation of the resultant logit regression model showed the relationship between the acceptance probabilities to the bid offered (WTP) for the ecosystem services derived from RAS and their covariates were examined (Table 3). Five significant variables were the bid offered, income, education, years of farming experience and attitude of RAS farmers. The likelihood ratio was 20.05 and 14.97 and the mean WTP value computed was $\$ 10.30$ /household/month and $\$ 10.50$ /household/month in Edo and Delta States respectively. With the population of 7,218,332 and 4,098,391 people in Edo and Delta States, the total WTP/year for these twelve ecosystem services listed were $\$ 74,565,369.6$ and $\$ 43,033,105.5$ in Edo and Delta States respectively. For the whole study area (Edo and Delta States), the total WTP/year is $\$ 117,598,475.1$. This in effect means that the total value of ecosystem services provided by RAS in the study area is $\$ 117,598,475.1$.

The log of the offered bid had a negative and significant effect $(\mathrm{p}<0.05)$ on the likelihood of bid acceptance for the ecosystem services provided by RAS in Edo and Delta States. Income had a negative and significant $(p<0.05)$ relationship with the likelihood of bid acceptance for the ecosystem services provided by RAS in Edo State while in Delta State, income had a negative and significant $(\mathrm{p}<0.01)$ relationship with the likelihood of bid acceptance for the ecosystem services. Education had a negative and significant $(\mathrm{p}<0.01)$ relationship with the likelihood in the WTP for RAS ecosystem services in Edo State while in Delta State, education had a negative and significant $(\mathrm{p}<0.05)$ relationship with the likelihood in the WTP for RAS ecosystem services. Years of farming experience had a positive and significant $(p<0.05)$ relationship on the likelihood in the WTP for RAS ecosystem services in Edo State while in Delta State, years of farming experience had a negative and significant $(\mathrm{p}<0.05)$ relationship on the likelihood in the WTP for RAS ecosystem services. The attitude of RAS farmers had a positive and significant $(\mathrm{p}<0.1)$ relationship with the likelihood in the WTP for ecosystem services in Edo and Delta States. 


\begin{tabular}{|c|c|c|c|c|}
\hline \multirow[t]{2}{*}{ WTP } & \multicolumn{2}{|c|}{ Edo State } & \multicolumn{2}{|c|}{ Delta State } \\
\hline & Coefficient & z-value & Coefficient & z-value \\
\hline Constant & 1.1665 & 0.43 & 1.69606 & 0.62 \\
\hline Bid & $-0.00296^{* *}$ & -2.20 & $-0.00295^{* *}$ & -2.23 \\
\hline Income & $-0.00467^{* *}$ & -2.33 & $-0.00014^{* * *}$ & -2.99 \\
\hline Education & $-0.22061^{* * *}$ & -4.47 & $-3.32278^{* *}$ & -2.52 \\
\hline Household size & 0.19919 & 1.02 & -0.11916 & -0.40 \\
\hline Gender & -2.5895 & -1.62 & 0.35215 & 0.30 \\
\hline $\begin{array}{l}\text { Years of farming } \\
\text { experience }\end{array}$ & $0.20079 * *$ & 2.23 & $-0.43430 * *$ & -2.46 \\
\hline $\begin{array}{c}\text { Contact with extension } \\
\text { officer }\end{array}$ & -1.50716 & -0.68 & 0.16925 & 0.21 \\
\hline RAS & $1.51758^{*}$ & 1.65 & $1.34497^{*}$ & 1.68 \\
\hline No. of observation & \multicolumn{2}{|c|}{60} & \multicolumn{2}{|c|}{60} \\
\hline Pseudo R-Square & \multicolumn{2}{|c|}{$48.8 \%$} & \multicolumn{2}{|c|}{$40.96 \%$} \\
\hline Likelihood Ratio Test & \multicolumn{2}{|c|}{20.05} & \multicolumn{2}{|c|}{14.97} \\
\hline $\begin{array}{l}\text { Mean Willingness-To- } \\
\text { Pay } \\
=\mathrm{X} / \text { Household/ month }\end{array}$ & \multicolumn{2}{|c|}{$\# 10.33$} & \multicolumn{2}{|c|}{$\# 10.50$} \\
\hline
\end{tabular}

Table 3: Maximum Likelihood Estimations of Responses to Willingness-To-Pay (WTP) Questions

Dependent Variable Is The Yes/No Responses To The Offered Bid Amounts.

*** Significant At 1\%,

**Significant At 5\%,

* Significant At 10\%

Source: Computed from Field Survey Data, 2019.

\section{Discussion}

The socio-economic characteristics of the respondents showed the distributions based on some variables such as gender, age, level of education and income. The distribution of gender in the study area showed that the farmers were predominantly males $(77.5 \%$ ). This percentage distribution was expected as the targeted respondents were cash crop farmers that deal solely on the cultivation of Rubber. This finding was in consonance with various authors (Larinde and Santus, 2014; Adeduntan, 2015; Okwu et al., 2018), they stated that farm practices especially tree and cash crops are labour intensive. The respondent's age ranged from 35 years to above 65 years in the study area. The dominant age of the respondents was within the age class of $46-55$ years in the study area. The species of focus in this study has a rotation age of 40 years, it is expected that farmers within this age range are most likely to engage in the cultivation of Rubber. Majority of the respondents attained both secondary and tertiary education, this shows that the respondents had some basic knowledge in agricultural practices, in addition, these farmers can be trained further on practices that will improve the cultivation and management of the species in focus. The highest monthly income reported by the respondents was between $\$ 50,000$ - $\$ 100,000$ in study area. This shows that the respondents can provide for their immediate family needs as well as afford basic necessities. According to El Tahir et al., (2015), who stated that adequate income to meet the needs of the households is the major factor in promoting agroforestry adoption and sustainability. Thus, RAS practice in the study area has positive impact on poverty alleviation through its contribution to farmer's income.

The summary of the regression analysis to determine the maximum likelihood estimations for the explanatory variables of respondents Willingness-To-Pay (WTP) showed that the likelihood ratio for the binary logit model (20.05 and 14.98) in Edo and Delta States respectively and the z-statistics for the regression are significant at $1 \%$ and $5 \%$, This means that the variables provide relevant information on the decisions of the respondents with regards to their willingness to pay for ecosystem services. The total WTP for the ecosystem services provided by RAS is $\$ 117,598,475.1$ per annum for the whole study area. This value represents the monetary value required as ecosystem service payment for the people in the study area to sustain the ecosystem benefits provided by RAS. According to Okojie and Abiola, (2014), the WTP for ecosystem services indicates a new era of environmental consciousness on the need to maintain ecological sustainability.

The log of bid offered had a negative and significant effect on the likelihood of the bid acceptance for ecosystem services provided by RAS. This finding corroborates that of Okojie and Abiola (2014), who stated that the higher the price of the environmental commodity, the lesser will be the demand. Furthermore, the significant test of the variables shows that the determinant variables of the respondent's decision to willing pay for ecosystem services are income, education, years of farming experience, attitude of RAS farmers. The negative and highly significant effect on the likelihood of the bid acceptance for income and educational level of respondents suggest that the higher the income and level of education of the respondent is associated with a lower tendency to pay for the ecosystem services from RAS. This implies that increase in income and level of education of the respondents reduces the likelihood in the WTP for ecosystem services provided by RAS, the reason being that as the level of education of the respondent's increases, increased proportion of income will be used to attain higher level of education, trainings, conferences and seminars thereby affecting downwards the likelihood in their WTP for ecosystem services provided by RAS. The positive and highly significant effect on the likelihood of the bid acceptance for respondents' years of farming experience and attitude of RAS farmers suggest that the higher the number of 
years of farming experience and the attitude of RAS farmers is associated with a higher tendency to willingly pay for the ecosystem services derived from RAS. Findings from this study are in line with previous studies on Willingness to pay for public goods and services (Adekunle and Agbaje, 2012; Okojie and Abiola, 2014; Sellers-Rubio and Nicolau-Gonzalbez, 2016).

Thus, the respondents have an understanding that RAS does not only contribute to social and economic benefits towards their livelihood but also contribute to ecosystem services within the RAS. Hence the need for the sustainable development of the Rubber Agroforestry System.

\section{Conclusion}

The aim of this research study has been to estimate respondents Willingness-To-Pay (WTP) for ecosystem services derived from Rubber Agroforestry System (RAS). This paper analyzed the WTP of farmers practicing RAS and the impact of various determining variables on the respondent's willingness to pay using the logit regression model. The result revealed five determining variables that affect the respondents WTP for ecosystem services. Also, socio-economic characteristics of the respondents play a significant role in predicting their willingness to pay for an ecosystem service. The research study has proven to contribute to literature on willingness to pay for a good and services obtained from a farming system. Findings from this study, will contribute additional information for decision and policy makers when designing and enacting laws for the sustainable use of the forest and its resources.

Conclusively, the result from this study has several implications for ecosystem services. Over the last two decades, the valuation of forests and its related systems around the world has included environmental, social and economic aspects of sustainable forest ecosystem and the associated management practices, which has created a great interest amongst research scientist. Forest either natural or man-made are an important economic resource and changes in the ecosystem especially in the area of not being able to regulate the global climate would lead to severe consequences such as widespread poverty, low agricultural productivity due to degrading natural resource base. The only option now left is to reverse the trend by using the available land more efficiently and sustainably as this will contribute in improving soil fertility and promoting agroecosystem function.

\section{References}

i. Adeduntan, S.A. (2015). Contribution of some ornamental plants to the socioeconomic development of urban household in Akure metropolis. African Journal of Agricultural Research. Vol. 10(4), pp. 264-268 DOI: 10.5897/AJAR2013.7945

ii. Adekunle, M.F. (2005). Economic Valuation of Forest Plants Used in Traditional Treatment of guinea worm (Drancunculus medinensis) Infection in Ogun State, Nigeria. Ph. D. thesis, Department of Forestry and Wildlife Management, University of Agriculture, Abeokuta, Nigeria (Unpublished), pp113-125.

iii. Adekunle, M. F. and Agbaje, B. M. (2012). Public willingness to pay for ecosystem service functions of a peri-urban forest near Abeokuta, Ogun State, Nigeria. Journal of Development and Agricultural Economics Vol. 4(2), pp. 45-50, Available online at http://www.academicjournals.org/JDAE DOI: 10.5897/JDAE11.085 ISSN 2006- 9774

iv. Ajewole, O.I. (2000). Economic valuation of forest environmental service functions of forest

v. in Ibadan metropolis. M. Phil. Thesis. Department of forest Resources Management, University of Ibadan (UI), Nigeria. pp 165

vi. Ajewole, O.I and Popoola L. (2001). Monetization of Forest service Functions for sustainable forest management. Journal of Environmental Extension, University of Ibadan, Vol. 1 pp. 117-125.

vii. Asaah E., Okwu, C., Esekhade, T., Osazuwa, E. and Onaiwu, B. (2014). Rubber Agroforestry: perspectives for smallholdings in Nigeria. Policy Brief No. 26, pp 1-4 Published by World Agroforestry Centre, and Rubber Research Institute of Nigeria.

viii. Cooper, J.C. and Loomis, J. (1992). Sensitivity of willingness-to-pay to bid design in dichotomous choice contingent valuation models. Land Economics 68(2): pp 211-224.

ix. Costanza, R., d'Arge, R., de Groot, R., Farber, S., Grasso, M., Hannon, B., Limburg, K., Naeem, S., O’Neill, R.V.,

x. Paruelo, J., Raskin, R.G., Sutton, P. and van den Belt, M. (1997). The Value of the World's Ecosystem Services and Natural Capital. Nature, 387, pp 253-260. http://dx.doi.org/10.1038/387253a0

xi. El Tahir, B.A. and Vishwanath, A. (2015). Estimation of Economic Value of Agroforestry Systems at the Local

xii. Scale in Eastern Sudan. Journal of Geoscience and Environment Protection, 3, pp38-56. http://dx.doi.org/10.4236/gep.2015.39005

xiii. Esekhade, T., Idoko, S., Mesike, S., Ubani, S., Balogun, F.E., Igbinosun, F., Okwu, C. and Asaah, E. (2014). Rubber Agroforestry options in Nigeria. Policy Brief No. 23. Pp 1-4 Published by World Agroforestry Centre, and Rubber Research Institute of Nigeria.

xiv. Frank, S. and Pieter van, B. (1997). Economic valuation of Mangrove ecosystems: Potential and limitation. CREED working paper, No. 14.

xv. Hanemann, W. M. (I994). Valuing the Environment through Contingent Valuation. Journal of Economic perspectives Vol. 8 (4) pp. 19 - 43

xvi. Kalish, S., Nelson, P., (1991). A comparison of ranking, rating and reservation price measurement in conjoint analysis. Mark. Lett. 2(4),327-335.

xvii. Larinde, S. L. and Santus, R. (2014). Assessment of Small-Scale Private Plant Nursery Enterprise in Port Harcourt, Rivers State. Department of Forestry \& Wildlife Management, Faculty

of Agriculture, University of Port 
Harcourt, Nigeria. Global Journal for Bio-science and Biotechnology. G.J.B.B., VOL.3 (3): pp 301-311

ISSN 2278 9103

xviii. Mather, A.S. and Chapman, K. (1995). Environmental resources. Longman Scientific and Technical England. $24-40$, pp $92-117$

xix. MEA. (2005). Ecosystems and Human Well-Being, Vol. 1. Current State and Trends. R. Hassan, R. Scholes and N. Ash (eds.), Millennium Ecosystem Assessment. Island Press, Washington DC, USA.

xx. Okojie, L.O. and Abiola, M.O. (2014). Willingness to pay for ecosystem benefits of Agroforestry driven green growth in Ogun State, Nigeria. Tanzania Journal of Forestry and Nature Conservation, Volume 83(2) pp.1-10

xxi. Okwu, C., Asaah E., Osazuwa, E., Onaiwu, B., Amanze J. and Anegbeh, P. (2014). Indigenous trees on farm in

xxii. Nigeria: tackling the triple challenge of mitigation, adaptation and food security in Nigeria. Policy Brief No. 27 pp 14. Published by World Agroforestry Centre, and Rubber Research Institute of Nigeria.

xxiii. Sellers-Rubio, R. and Nicolau-Gonzalbez, J.L., (2016). Estimating the willingness to pay for a sustainable wine using a Heckit model. Wine Economics and Policy 5, 96-104

xxiv. Sukhdev, P. (2010). TEEB-Mainstreaming the Economics of Nature: A Synthesis of the Approach, Conclusions and Recommendations of TEEB. http://teebweb.org

xxv. Turcin B. and Giraud K. (2001). Contingent valuation willingness to pay with respect to geographical nested samples: case study of Alaskan Stellar Sea Lion, W-133 Western Regional Project Technical Meeting Proceedings

xxvi. Varian, H.R., (1992). Microeconomic analysis. W.W. Norton, New York

xxvii. White, P.C.L and Lovett, J.C. (1999). Public preferences and Willingness-To-Pay for nature conservation in the North New York Moors national park, U.K. Journal of Environmental management 55: pp 1-13 